\title{
The Influence of Leadership and Work Environment toward Organziational Citizenship Behavior (OCB) through Work Satisfaction
}

\author{
Argo Ahmad1, Dedi Purwana*, Ari Saptono \\ 1 Universitas Negeri Jakarta, Indonesia
}

Corresponding Author: Dedi Purwana, @ dpurwana@unj.ac.id*

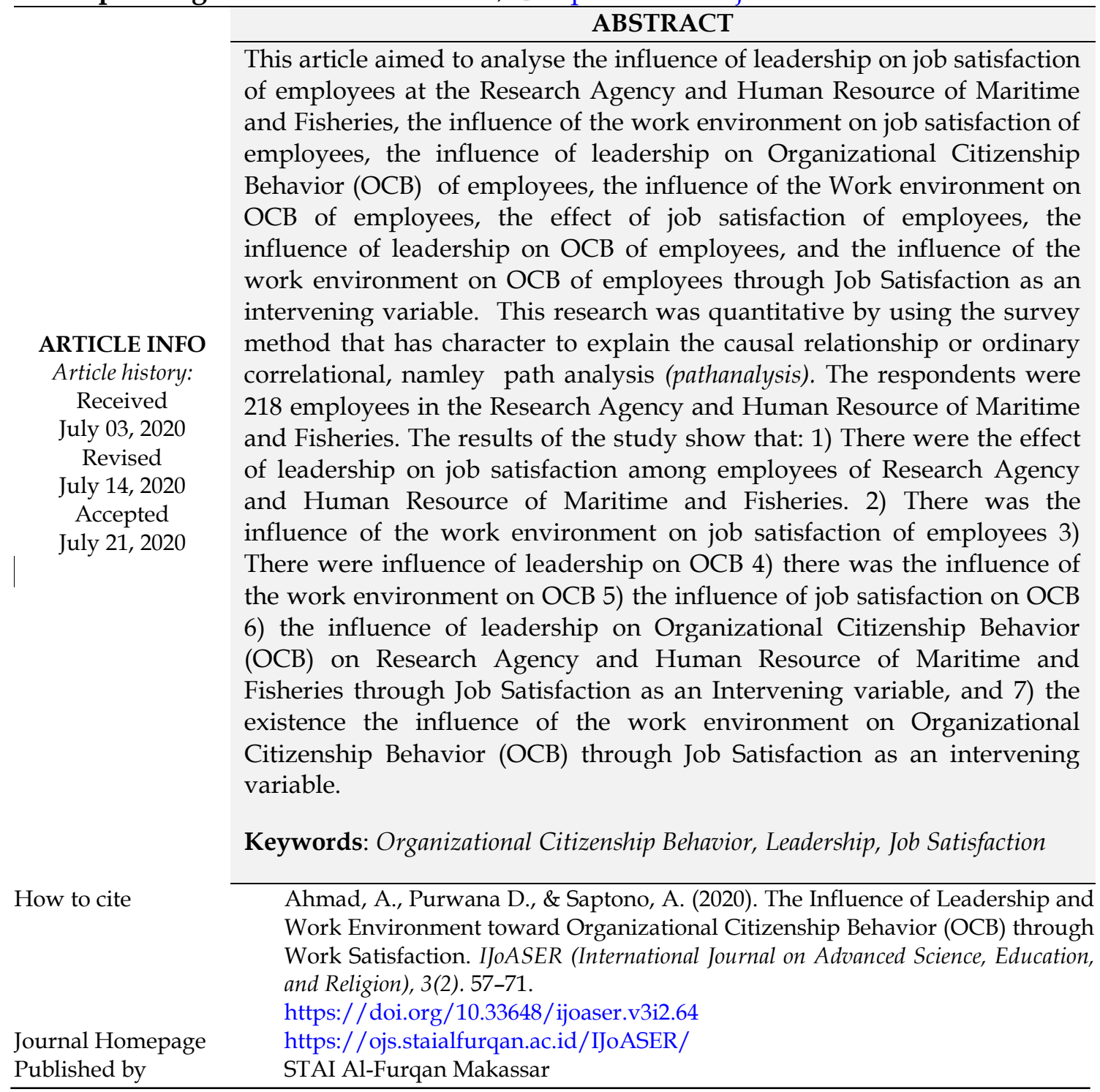

\section{INTRODUCTION}

Organizational Citizenship Behavior (OCB) is part of organizational behavior. The personality basis for OCB reflects the characteristics of employees who are cooperative, helpful, caring and earnest. While the basic attitude indicates that employees involved in OCB to reciprocate organizational actions (Duha, 2018). Organs (Nielsen et al, 2012) argue that OCB is an extra individual behavior, which is not directly or explicitly recognizable in a formal work system, and which in the aggregate is able to increase the effectiveness of organizational functions. Then for further 
research was to formulate OCB deeper, namely the contribution to the maintenance and improvement of the social and psychological context of task support. It is behavior tends to see employees as social beings who are members of the organization, rather than as individual beings who are selfish (Salunke, 2015; Boxall, P., \& Purcell, J. (2011). As social creatures, humans have the ability to emphasize with others and organizations, and balance the values they hold with the values of the organization (Robbin, 2011; Supriadi et al., 2016). It is done to maintain and enhance better social interaction. If the employee has citizen behavior, it has the effort to control the employee decreases, because the employee can control his own behavior or be able to choose the best behavior for the organization's interests. Precisely OCB is a special type of organizational behavior needed for the growth and success of each organization. Although this kind of behavior is not a mandatory factor to be maintained in the Organization but it is still a vital and important aspect in the growth of every organization (Ahmadi et al, 2011).

The research problem is the lack of leadership role in creating harmonious communication and giving good behavior to employees. Likewise, the lack of job satisfaction Leadership to employees with what has been done. In addition, the work environment is less instilled in good employee behavior to be more able to produce better behavior for the benefit of the organization. The behavior will not receive direct rewards or sanctions whether done or not, but the constructive attitude shown by employees through OCB will provide a positive assessment (Nielsen, 2012; Tabatabei, 2015). Organizations need employees who join good citizenship behaviors, such as in constructive statements about work groups and their organizations, help others in their teams, volunteer for additional activities, avoid unnecessary conflicts, show concern for property organization, respect the spirit as well as rules and rules centered, and willing to tolerate disturbances and losses associated with precarious work. In the dynamic world of work as it is today, where tasks are increasingly being done in teams and flexibility of good organizational citizenship behavior, such as helping other individuals in the team, advancing to carry out extra work, avoiding conflicts that do not need to respect the spirit and contents of the rules, and also with a great heart tolerate the loss and disruption associated with work that occurs (Garay, 2006). Based on the opinion above, OCB is part of organizational behavior. The personality basis for OCB reflects the characteristics of employees who are cooperative, helpful, caring and earnest with indicators: 1) helping behavior, 2) civic virtue, and 3) sportsmanship.

In previous studies, there were many researchers who discussed Organizational Citizenship Behavior (OCB), as has been done in Kartini's research. This study proves that leadership has a positive influence on Organizational Citizenship Behavior (OCB) (Kartini, 2017). In addition to the Leadership factor, Organizational Citizenship Behavior (OCB) is also influenced by the Organizational Work Environment as conducted in previous researchers proves that the work environment has a positive influence on Organizational Citizenship Behavior (OCB) (Suhardi \& Syaifullah, 2017). In other studies that affect Organizational Citizenship Behavior (OCB) is job satisfaction, as in research (Dewi, Yanti \& Suwandana, 2016) proven that job satisfaction has a significant positive effect on Organizational Citizenship Behavior (OCB). Different from those previous studies, this current research were more complex that analyse of leadership, work environment on Organizational Citizenship Behavior (OCB) through Job Satisfaction as an Intervening Variable on the Secretariat of the Research Agency and Human Resource of Maritime and Fisheries. 


\section{METHODS}

This research was quantitative study by using survey methods. The survey research was intended to explain causal relationships or correlations that are commonly disputed by pathanalysis. The sample of this study was 218 employees of the Research Agency and Human Resource of Maritime and Fisheries. The sampling technique used saturated sample (sample jenuh). This technique was chosen based on the consideration that the researcher would use data analysis techniques using AMOS which requires a lot of research samples. Data analysis technique used in this studyused SEM (structural equation modeling).

\section{RESULT AND DISCUSSION \\ Fit AMOS models}

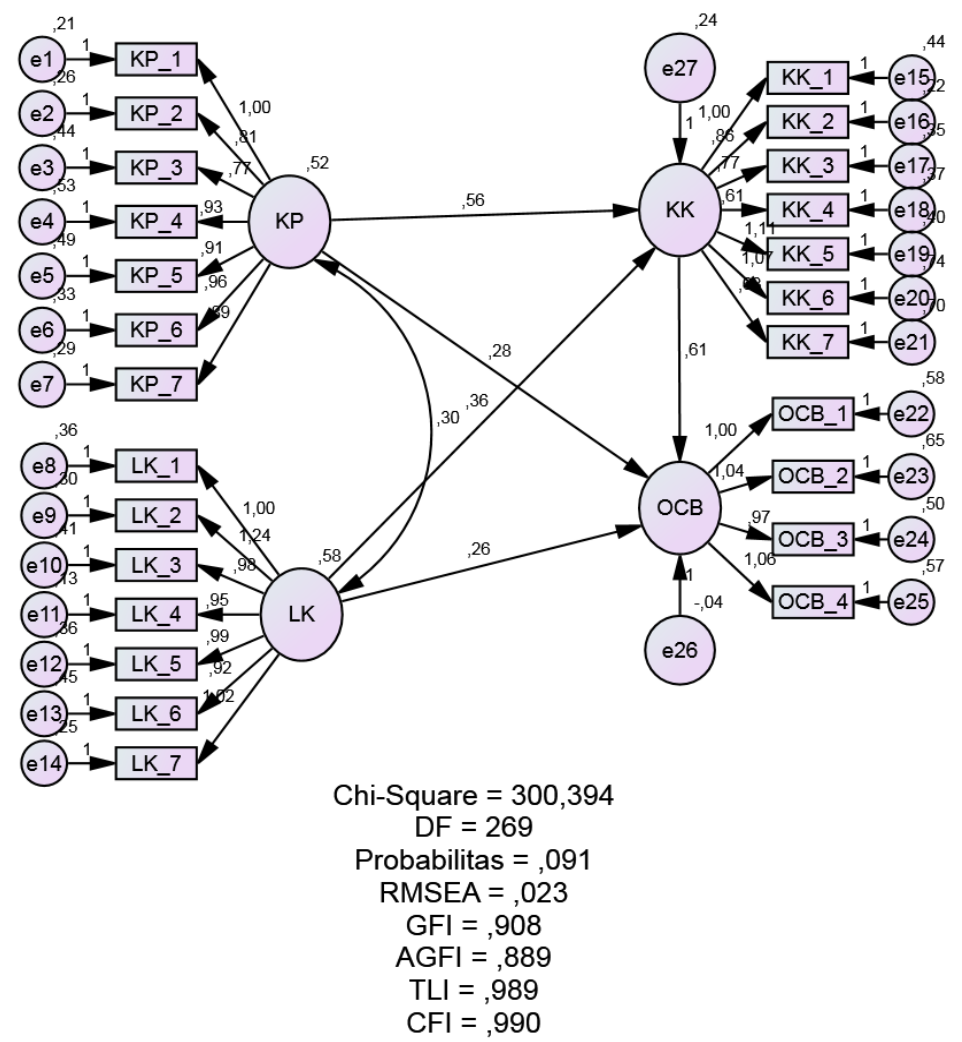

Table 1.

FullModel SEM

\begin{tabular}{cccc}
\hline Index & Cut Off Value & Results & $\begin{array}{c}\text { Evaluation } \\
\text { Model }\end{array}$ \\
\hline RMSEA & $\leq 0.08$ & 0.023 & Fitted \\
\hline GFI & $\geq 0.90$ & 0.908 & Fitted \\
\hline CFI & $\geq 0.95$ & 0.990 & Marginal Fitted \\
\hline CMIN/DF & $\leq 2.00$ & 1,117 & Fitted \\
\hline RMR & $\leq 0.05$ & 0.035 & Fitted \\
\hline AGFI & $\geq 0.90$ & 0.889 & Marginal Fitted \\
\hline
\end{tabular}

Source: Processed by researchers (2019)

Based on the table goodness of fit above, it can be concluded that the model meets the index criteria goodness of fit. Therefore, modification of the model is not needed in 
order to find a fit model in accordance with the criteria for goodness of fit. The first order construct stage of leadership variables has 1 factor with 7 indicators. After processing the model in the fit analysis of the AMOS model, no indicators were eliminated. The first order construct stage of the work environment variable has 1 factor with 7 indicators. After processing the model in the fit analysis of the AMOS model, no indicators must be eliminated. The first order construct phase of the OCB variable has 1 factor with 4 indicators. After processing the model in the full AMOS model analysis, the first factor was not eliminated.

Then the model fitness test (goodness of fit test) is performed by looking at the values in the predetermined criteria to find out whether the full AMOS model is fit or not. RMSEA value is 0.023, GFI is 0.908, CFI is 0.990, CMIN / DF is 1,117, RMR is 0.035, and AGFI is 0.889. Based on these results the six measurement models (P, RMSEA, GFI, CFI, RMR, and AGFI) show good numbers in accordance with the index criteria, this indicates that the model is fully fit with existing data, there are 2 criteria that are margin fit.

Table 2.

Indicators Fit Model

\begin{tabular}{|c|c|}
\hline Items & Statement \\
\hline \multicolumn{2}{|r|}{ Leadership } \\
\hline KP1 & Leaders have good relations with me and all employees \\
\hline KP2 & Leaders pay attention to the welfare of their employees \\
\hline KP3 & Leaders are fair to all of their employees \\
\hline $\mathrm{KP} 4$ & $\begin{array}{l}\text { Leaders give direction to their employees in completing their } \\
\text { tasks }\end{array}$ \\
\hline KP5 & Leaders complete their duties of their duties \\
\hline KP6 & Leaders support the achieve of institutions. \\
\hline KP7 & $\begin{array}{l}\text { leadership has the responsibility in achieving the goals of the } \\
\text { agencies }\end{array}$ \\
\hline \multicolumn{2}{|r|}{ Work Environment. } \\
\hline LK1 & $\begin{array}{l}\text { lighting (sunlight and electricity) in my workspace is in } \\
\text { accordance with needs. }\end{array}$ \\
\hline LK2 & I participate in maintaining cleanliness in workplaces \\
\hline LK3 & $\begin{array}{l}\text { The air condition in my workspace provides comfort while } \\
\text { working }\end{array}$ \\
\hline LK4 & Noising disturbs when I work \\
\hline LK5 & $\begin{array}{l}\text { I have the opportunity to grow in ability, knowledge and } \\
\text { career. }\end{array}$ \\
\hline LK6 & Leaders pay attention and support to me \\
\hline LK7 & Communication goes well, both directly and indirectly \\
\hline \multicolumn{2}{|r|}{ Job Satisfaction } \\
\hline KK1 & I do work now as wish \\
\hline KK2 & I feel comfortable with the work that done \\
\hline KK3 & I receive benefits for work \\
\hline KK4 & I receive health insurance \\
\hline KK5 & I am satisfied with the assessment conducted by the leader \\
\hline KK6 The & $\begin{array}{l}\text { leader demands the achievement of targets to me when } \\
\text { working in accordance with his duties }\end{array}$ \\
\hline
\end{tabular}




\begin{tabular}{cl}
\hline KK7 & I have given the opportunity of education \& training \\
\hline OCB1 & $\begin{array}{l}\text { I have been happy to help my coworkers who need help } \\
\text { without expecting rewards }\end{array}$ \\
\hline OCB2 & $\begin{array}{l}\text { Every assignment given to me, I will finish with full } \\
\text { responsibility }\end{array}$ \\
\hline $\begin{array}{c}\text { OCB3ad } \\
\text { opts }\end{array}$ & $\begin{array}{l}\text { If the Agency a new policy and is not in accordance with my } \\
\text { opinion. I will adjust and implement the policy }\end{array}$ \\
\hline OCB4 & I appreciate every opinion who expressed by coworkers \\
\hline & Source: Processed by researchers (2020)
\end{tabular}

Direct and Indirect Influencing

Table 3.

The Influence of Direct and Indirect Effects

\begin{tabular}{ccccc}
\hline Bound Variable & Free Variables & Direct Effect & $\begin{array}{c}\text { Indirect } \\
\text { Effect }\end{array}$ \\
\hline Job Satisfaction & $\leftarrow$ & Leadership & 0.563 & - \\
\hline $\begin{array}{c}\text { Job of Work } \\
\text { Satisfaction }\end{array}$ & $\leftarrow$ & Environment & 0.362 & - \\
\hline OCB & $\leftarrow$ & Leadership & 0.285 & 0.342 \\
\hline OCB & $\leftarrow$ & $\begin{array}{c}\text { Work } \\
\text { Environment }\end{array}$ & 0.262 & 0.220 \\
\hline OCB & $\leftarrow$ & $\begin{array}{c}\text { Job } \\
\text { Satisfaction }\end{array}$ & 0.608 & - \\
\hline
\end{tabular}

Source: Data processed by Researchers, 2019

Test of direct and indirect effects was carried out to determine whether there are direct or indirect influences independent variables that affect the dependent variable. Based on the results of data analysis, it can be analyzed that the direct effect of leadership variables on Job Satisfaction was 0.563. The direct effect of the Work Environment variable on Job Satisfaction was 0.362. The direct influence of leadership variables on OCB was 0.285, indirect effect 0.342. The direct effect of Work environment variables on OCB was 0.262. Indirect effect was 0.220 and the direct effect of the Job Satisfaction variable on OCB was 0.608 . The indirect effect is only owned by the leadership and work environment variables on OCB. It was due to the mediating variables in the research model between leadership and work environment towards OCB, namely the Job Satisfaction variable.

\section{Hypothesis Test}

If the $t$-value in the structural equation model results is greater than 1.96, then there is a significant influence between variables. Meanwhile, if the $t$-value is smaller than 1.96, then the influence between the variables is not significant

Figure 3.

Hypothesis testing

Source: data processed by researchers (2019) 


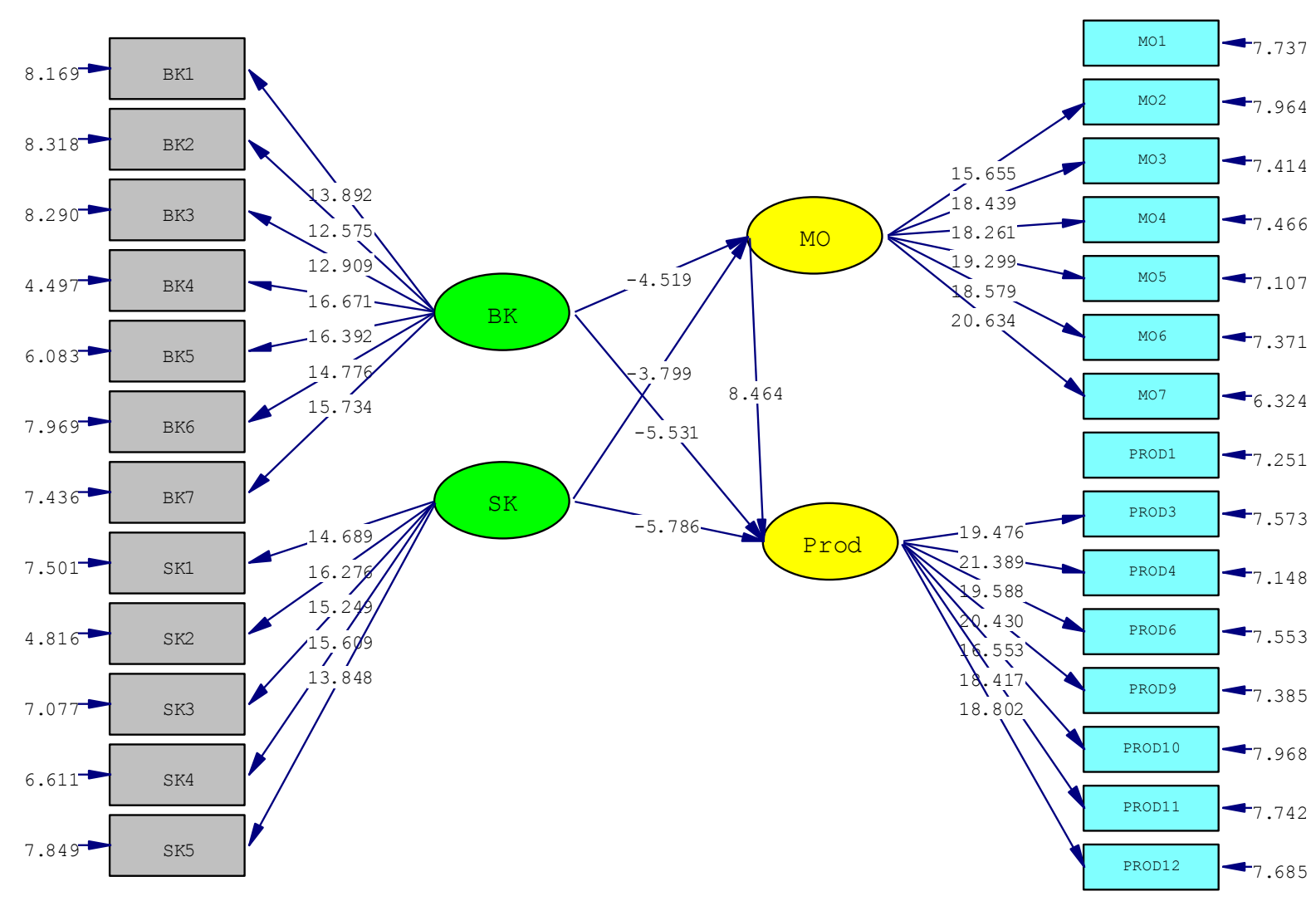

Chi-Square $=333.94, \mathrm{df}=318, \mathrm{P}-\mathrm{value}=0.25842, \mathrm{RMSEA}=0.019$

Table 4.

Structural Equation Model

\begin{tabular}{|c|c|c|c|c|c|c|}
\hline \multirow{2}{*}{$\begin{array}{l}\frac{n}{0} \\
0 \\
0 \\
0 \\
01\end{array}$} & \multirow[b]{2}{*}{$\begin{array}{c}\text { Bound } \\
\text { Variables }\end{array}$} & & \multirow[b]{2}{*}{ Free Variables } & \\
\hline & & & & t-value & $\begin{array}{c}\text { Standardiz } \\
\text { e Total } \\
\text { Effects }\end{array}$ & Interpretation \\
\hline $\begin{array}{l}\mathrm{H} \\
1 \mathrm{a}\end{array}$ & $\begin{array}{l}\text { Kepuasan } \\
\text { kerja }\end{array}$ & $\leftarrow$ & Leadership & -4.519 & -0.358 & Accepted \\
\hline $\begin{array}{l}\mathrm{H} \\
1 \mathrm{~b}\end{array}$ & OCB & $\leftarrow$ & Leadership & -5.531 & -0.301 & Accepted \\
\hline $\begin{array}{l}\mathrm{H} \\
2 \mathrm{a}\end{array}$ & $\begin{array}{l}\text { Kepuasan } \\
\text { kerja }\end{array}$ & $\leftarrow$ & $\begin{array}{l}\text { Work } \\
\text { Environment }\end{array}$ & -3.799 & -0.297 & Accepted \\
\hline $\begin{array}{l}\mathrm{H} \\
2 \mathrm{~b}\end{array}$ & OCB & $\leftarrow$ & $\begin{array}{l}\text { Work } \\
\text { Environment }\end{array}$ & -5.786 & -0.311 & Accepted \\
\hline $\begin{array}{c}\mathrm{H} \\
3\end{array}$ & OCB & $\leftarrow$ & Job Satisfaction & 8.464 & 0.500 & Accepted \\
\hline
\end{tabular}

Source: Processed by researchers (2019))

Based on the results of the structural equation model above, all relationships between variables have t-values, greater than 1.96 or -1.96 . It means that there is a significant influence between variables. Hypothesis testing is done by looking at the value of standardized total effects in the structural equation model. Then it can be seen the results of the hypothesis test as follows: 
1. The leadership variable on Job Satisfaction in the Research Agency and Human Resource of Maritime and Fisheries has a standardized total effects value of 0.563. Hence hypothesis 1a which states leadership on Job Satisfaction can be accepted that has an effect of $56.3 \%$.

2. Variable work environment towards job satisfaction at the Research Agency and Human Resource of Maritime and Fisheries has a standardized total effects value, that is 0.362 . So that hypothesis 2 which states the work environment on job satisfaction has an effect of $36.2 \%$. It is acceptable.

3. The leadership variable on OCB at Research Agency and Human Resource of Maritime and Fisheries has a standardized total effects value of 0.285 . Hence the hypothesis 3 which states leadership towards OCB has an effect of $28.5 \%$. It is acceptable.

4. The work environment variable on OCB at the Research Agency and Human Resource of Maritime and Fisheries has a standardized total effects value of 0.262.So, hypothesis 4 which states the working environment on OCB has an effect of $26.2 \%$ and it is acceptable.

5. Job Satisfaction variable for OCB at the Research Agency and Human Resource of Maritime and Fisheries has a standardized total effects value of 0.608 . So that hypothesis 5 which states Job Satisfaction for OCB has an effect of $60.8 \%$ and it is acceptable.

6. The leadership variable on OCB mediated by job satisfaction at the Maritime and Fisheries Research and HR Agency has a standardized indirect effects value of 0.328 , so hypothesis 6 which states that leadership towards OCB is mediated by job satisfaction has an effect of $32.8 \%$ and is acceptable.

7. Work environment variables on OCB mediated by job satisfaction at the Maritime and Fisheries Research and HR Agency have a standardized indirect effects value of 0.222 , so hypothesis 7 which states the work environment of OCB mediated by job satisfaction has an effect of $22.2 \%$ and is acceptable.

\section{Sobel Test:}

The Effect of Leadership on OCB with Mediated Job Satisfaction

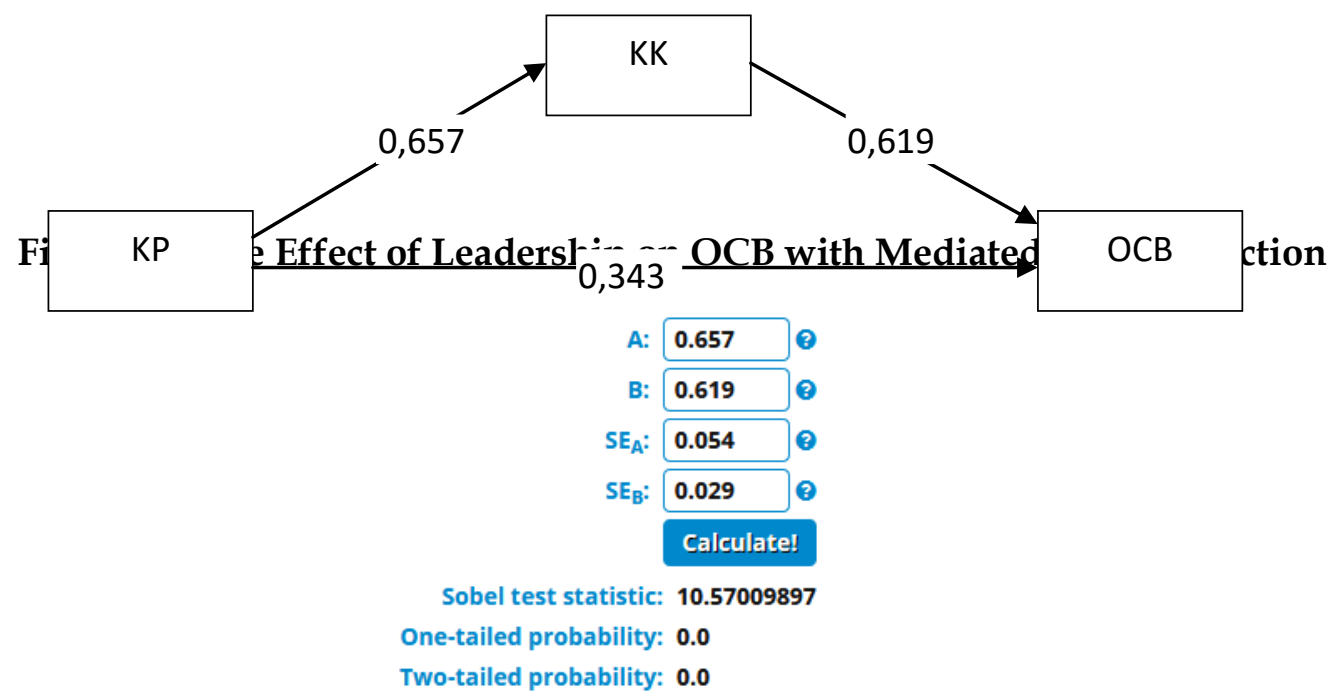

Figure 3. Sobel Test 
The results of the analysis with the sobel test show that the statistical value (zvalue) for the influence of job satisfaction as an intervening variable between leadership variables and OCB was 10.57009897 and significant on Two-tailed probability with 0.00 . Because $\mathrm{z}$-value $>1.96$ or $\mathrm{p}$-value $<\alpha=0.05$. It can be concluded that the effect or indirect effect is significant, the mediation hypothesis is supported.

The Effect of Work Environment on OCB with Intervening Variables Job Satisfaction

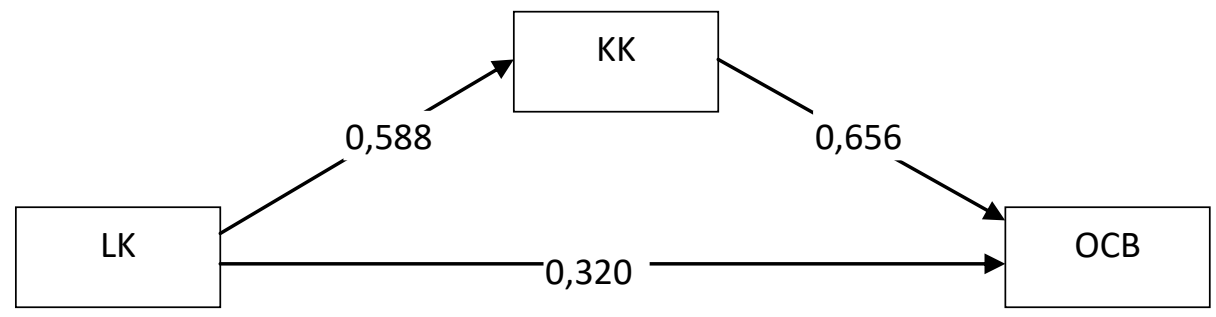

Figure 4.9 Effect of Work Environment on OCB with Intervening Variables Job Satisfaction

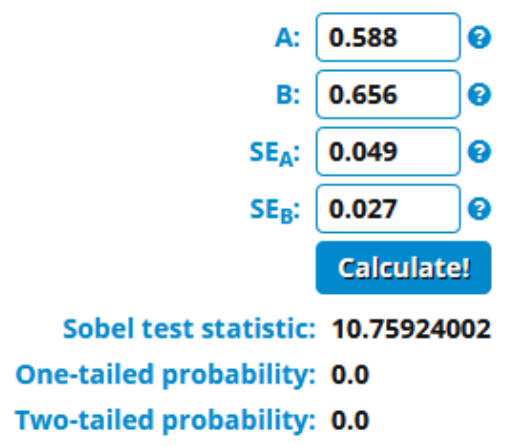

Figure 4. Sobel Test

The results of the analysis Sobel test show that the statistical value (z-value) for the influence of motivation variables as intervening variables between environmental variables employment and OCB of 10.75924002 and significant at Two-tailed probability with the number 0.00 . Because $z$-value $>1.96$ or $p$-value $<\alpha=0.05$. It can be concluded that the effect or indirect effect is significant. In line with previous findings using standardize total effects. The mediation hypothesis is supported.

The Leadership has a Positive Effect on Job Satisfaction Employees of Research Agency and Human Resource of Maritime and Fisheries

The results of this study proven that the leadership on job satisfaction employees of Research Agency and Human Resource of Maritime and Fisheries has a standardized total effects value, that is 0.563 . So that the hypothesis leadership influences satisfaction work was $56.3 \%$ and It is acceptable.

The results of this study are in line with research conducted by Al-Swidi et al. (2012) stated that leadership has been shown to have a significant effect on employee 
job satisfaction through increasing the perception of employee empowerment. It is related to employee self development for a better future.

Other research research was conducted by Hariyansyah (2014), It concluded that Leadership has a positive effect on Job Satisfaction. While research was conducted by Supit (2016) with the title Effect of Transformational Leadership Style Towards Organizational Commitment and Organizational Citizenship Behavior Mediated by Job Satisfaction, It concluded that Transformational Leadership has a significant influence on job satisfaction. In line with the result Asghar \& Oino (2018), who concluded that the transformational leadership style has a positive effect on job satisfaction, while the transactional leadership style has an insignificant effect on job satisfaction. Therefore, it can be argued that the transformational leadership style is more effective in the retail sector of Slough, United Kingdom. Javed, Abbas \& Rahim (2014) in his research also concluded that, the relationship between transactional leadership style and employees' job satisfaction and this transactional leadership style is more adopted by the leaders as compared to transformational leadership style. Other research results are very important for the higher management of targeted banks in terms of to increase employees' job satisfaction they can train their leading staff in branches to adopt transactional leadership styles (Nasra \& Heilburn, 2015). This research article comes to an end with a brief conclusion, limitations and recommendations.

Work Environment Has a Positive Effect on Job Satisfaction of Employees of Research Agency and Human Resource of Maritime and Fisheries.

The results of this study prove that the work environment influences job satisfaction employees of Research Agency and Human Resource of Maritime and Fisheries. The employeeshave a standardized total effects value, that is 0.362 . Hence, hypothesis stating the work environment effect on job satisfaction was $36.2 \%$ and it can be accepted.

This finding supports by Priansa (2014) who said that "Job satisfaction is a set of employees' feelings towards their work, whether they like / dislike or dislike / dislike as a result of employee interaction with their work environment or as a result of employee appraisal of their work. With good working conditions, employees will feel satisfaction with their work. This finding are also supported by other results who conducted by Aruan \& Fakhri (2015), with the title Effect of Work Environment on Job Satisfaction of Field Employees at Grasberg Power Distribution Department of PT. Freeport Indonesia. The result concluded that the Work Environment has a positive and significant effect on Job Satisfaction. While research conducted by Wibowo, Al Musadieq \& Nurtjahjono \& Danang concluded that the Work Environment has a positive and significant effect on Job Satisfaction (Al Musadieq \& Nurtjahjono; Danang, 2013). Raziqa \& Maulabakhsha, 2015) also examined the Impact of Working Environment on Job Satisfaction. The results of his research concluded that the businesses need to realize the importance of a good working environment for maximizing the level of job satisfaction. Ganesh Salunke's research (2015) also concluded that the work environment \& its effect on job satisfaction in the cooperative sugar factories. This study is conducted in Maharashtra.

From the explanation above it can be concluded that increasing employee job satisfaction is an organization that is expected to be able to improve physical work environment facilities. Because physical work environment variables have a dominant influence in influencing employee job satisfaction, including by improving the quality 
of workspace layout, lighting, air circulation, working equipment condition, safety level, noise, and cleanliness. so employee job satisfaction will increase.

The Leadership has a Positive Effect on Organizational Citizenship Behavior (OCB) of employees at Research Agency and Human Resource of Maritime and Fisheries

The results of this study prove that there is a significant positive influence of leadership on OCB employees Research Agency and Human Resource of Maritime and Fisheries. It having standardized total effects was 0.285 . So,the hypothesis $2 \mathrm{a}$ which states leadership on motivation has an effect of $28.5 \%$ and it is acceptable.

The results of this study are in line with Andreas (2011) who reported that OCB has characteristics of voluntary behavior (extra-role-behavour), which are not included in job descriptions, spontaneous behavior without someone's advice or commands, helpful behavior, and behavior that is not easy seen and assessed through performance evaluation. Leadership has an important role in Organizational Citizenship Behavior (OCB) and can have leadership behaviors that act according to organizational goals. Mewanwhile, Nawawi (2018) said that Leadership is "The ability and skills to direct, that is an important factor (activity) in the effectiveness of leaders. So that it will affect one's leadership behavior.

Other research who conducted by Supriadi, Hardhienata, \& Retnowati (2016) with the title The Relationship of Transformational Leadership, Personality and Job Satisfaction to Organizational Citizenship Behavior (OCB), concluded that transformational leadership has a positive and significant effect on OCB. While other research entitle Organizational Citizenship Behavior Role in Mediating the Effect of Transformational Leadership, Job Satisfaction on Employee Performance: Studies in PT Bank Syariah Mandiri Malang East Java concluded that transformational leadership does not affect OCB, OCB Affects directly on employee performance, transformational leadership Affects directly on employee performance, job satisfaction Affects directly on employee performance, OCB does not mediate the effect of transformational leadership on employee performance, OCB mediates the effect of job satisfaction on employee performance (Jackon \& Mathis, 2010; Troena \& Noermijati, 2013; Kirana, K. C., \& Ratnasari, R. T. (2017)

From the above explanation it can be concluded that Leadership with ability and skills can also provide good behavior towards behavior that is not easily seen and assessed through performance evaluation. So that leaders with Organizational Citizenship Behavior (OCB) can provide good behavior to their subordinates. It means that by increasing leadership the employee will have a high enough organizational citizenship behavior.

\section{Work Environment has a Positive Effect on OCB of Employees at Research Agency and Human Resource of Maritime and Fisheries}

The results of this study proven that there is a significant positive influence on the work environment for OCB employees of the Research Agency and Human Resource have a standardized total effects value of 0.262 , so hypothesis $2 b$ which states the working environment on OCB has an effect of $26.2 \%$ acceptable.

According to Budiyanto \& Oetomo (2011) reported that Work environment creates high comfort for employees. The comfort created from this work environment has an effect on the seriousness of employees in working so as to encourage employees to work better because of environmental support. The Work Environment has an important role in Organizational Citizenship Behavior (OCB) and can have the behavior 
of employees who work to be comfortable. According to Turnley \& Bloodgood (2002), OCB is employee behavior that exceeds the mandatory role, which is not directly or explicitly recognized by the reward formal system. It is a selective behavior that is not part of an employee's formal work obligations, but instead supports the functioning of the organization directly effective.

Other research who conducted by Nurhayati, Maria, \& Heru (2016), with the title Influence of Job Satisfaction, Work Environment and Work Loyalty to Organizational Citizenship Behavior (OCB) (Case Study at PT. Perwira bhakti Sentraseak Center in Semarang City). The result concluded that the Work Environment has a positive effect on OCB. While other research Suhardi \& Syaifullah with the had a positive effect on OCB (Suhardi \& Syaifullah, 2017; Dakir, H, 2019). Nurhidayah et al., (2015) entitle on Organizational Culture and Work Environment: Its Effect on Teachers Organizational Citizenship Behavior (OCB), concluded that: Firstly, there is the influence of organizational culture by organizational citizenship behavior; Secondly, there is the influence of work environment by organizational citizenship behavior; Third, there is the influence of organizational culture on work environment (Nurhidayah et al., 2015).

From the explanation above, it can be concluded that the better the work environment, the higher the Organizational Citizenship Behavior (OCB) will be. Hence, the Work Environment with Organizational Citizenship Behavior (OCB) can provide good behavior towards subordinates. It means that by improving the Work Environment, employees will have high organizational citizenship behavior.

\section{Job Satisfaction has a Positive Effect on OCB of of Employees at Research Agency and Human Resource of Maritime and Fisheries}

The results of this study prove that there is a significant positive effect on job satisfaction on OCB on Maritime and Fisheries Research and HR Agency employees having a standardized total effects value of 0.608 . So, hypothesis 3 states that job satisfaction with OCB has an effect of $60.8 \%$ and it is acceptable.

The results of this study are in line with Priansa (2014) who reported that "Job satisfaction is a set of employees' feelings towards their work, whether they like / dislike or dislike / dislike as a result of employee interactions with their work environment or as a result of employee evaluations of their work.

Other research Rohayati (2014) concluded that Job Satisfaction has a positive and significant effect on Organizational Citizenship Behavior. While, Dewi et al., (2016) with the title Effect of Job Satisfaction on Organizational Citizenship Behavior (OCB) With Organizational Commitment as Mediation Variables concludes that Job Satisfaction has a positive and significant effect on Organizational Citizenship Behavior. Saxenaa et al., (2019) examined the Impact of Job Satisfaction on Organizational Citizenship Behavior which concluded that indicated a positive linear relationship between job satisfaction and organizational citizenship behavior. The finding is also supported that there is no difference between males and females on job satisfaction and organizational citizenship behavior.

From the explanation above, it can be concluded that the level of Organizational Citizenship Behavior (OCB) is high and low as a result of the high and low quality of job satisfaction that runs. The higher quality of job satisfaction that runs can provide great potential for the creation of high Organizational Citizenship Behavior (OCB). The lower the quality of job satisfaction that runs, it provides the potential for the creation of low Organizational Citizenship Behavior (OCB). 
The Leadership has a Positive Effect on OCB through Job Satisfaction as an Intervening Variable on the Employees at Research Agency and Human Resource of Maritime and Fisheries

The results of this study prove that there is a significant positive influence of leadership on OCB through job satisfaction as an intervening variable on the employees at Research Agency and Human Resource of Maritime and Fisheries. It has a standardized value indirect effect, which is 0.328 . The hypothesis 6 which states leadership affects OCB through job satisfaction is $32.8 \%$ and it can be accepted.

This result in line with research Agus et al., (2018) with the title The Effect of Leadership on Organizational Citizenship Behavior Through Work Climate and Job Satisfaction. The result shows that leadership has a significant effect on work climate, job satisfaction and organizational citizenship behavior.

Based on the results of this study, the results show that to produce good OCB, leadership and job satisfaction are also needed to influence it. As a mediating variable job satisfaction cannot be ignored, hence employee OCB increases.

\section{Work Environment has a Positive Effect on OCB through Job Satisfaction as an Intervening Variable on the Employees at Research Agency and Human Resource of Maritime and Fisheries}

The results of this study prove that there is a significant positive influence on the work environment on OCB through job satisfaction as an intervening variable on the employees of the Research Agency and the Maritime Human Resources and Fisheries. It has a standardized indirect effects value of 0.222 , so hypothesis 7 which states the work environment influences OCB through job satisfaction is $22.2 \%$ and can be accepted.

The results of this study are in line with Alif with the title influence of work motivation, career development and work environment on organizational citizenship behavior (OCB) with job satisfaction as an intervening variable in LPG terminal companies. The result showed that the Work Environment has a positive effect on OCB through job satisfaction as an intervening media (Alif, 2015).

Permana, Lely, \& Mufida (2016) examined the Influence of Organizational Culture, Motivation, Work Environment on Organizational Citizenship Behavior through Job Satisfaction at PT Kereta Api Indonesia (Persero) Operating Area 9 Jember. The results showed that the three independent variables and one Intervening variables that have the greatest influence on OCB are organizational culture variables with a coefficient 0.591 and job satisfaction with a coefficient 0.555. It indicated that organizational culture, and job satisfaction are important factors in growing the characteristics of OCB on employees of PT KAI DAOP 9 Jember. It was supported by other variables, namely motivation and work environment (Wibowo, 2018).

Pitaloka \& Sofia (2014) examined the Affect of Work Environment, Job Satisfaction, Organization Commitment on OCB of Internal Auditors. The results of his study concluded that the work environment is antecedent of job satisfaction and organizational commitment of internal auditors. Job satisfaction and organizational commitment significantly affect organizational citizenship behavior of internal auditors.

Based on the description above, job satisfaction is one of the factors that also influence the work environment with OCB. If the company wants to increase OCB, in addition to work environment variables, job satisfaction variables must also be considered or improved in order to increases. 


\section{CONCLUSIONS}

The leadership variable has a positive and significant effect on job satisfaction of employees of Marine and Fisheries Research and Human Resources Agency. It having a Standardize total effects value of 0.563. So that Hypothesis 1 has a positive effect, that is $56.3 \%$. Work environment variables have a positive and significant effect on employee job satisfaction and have a Standardize total effect of 0.362. So that hypothesis 2 has a positive effect, that is $36.2 \%$. The leadership variable has a positive and significant effect on employee OCB and has a total effect of 0.285 . Hence, the hypothesis 3 has a positive effect, that is $28.5 \%$. The work environment variable has a positive and significant effect on employee OCB and it has a total effect 0.262 . So, the work environment has a positive effect, which is $26.2 \%$. Job satisfaction variable has a positive and significant effect on employee OCB and has a standardize total effects, that is 0.608 . So that job satisfaction has a positive effect, that is $60.8 \%$. Leadership variables have a positive and significant effect on OCB through employee job satisfaction and have an indirect standardize effect of 0.328 . So, the leadership that has a positive effect on OCB through job satisfaction, that is $32.8 \%$. Work environment variables have a positive and significant effect on OCB through employee job satisfaction and have an indirect standardize effect, that is 0.222 . So that the work environment that has a positive effect on OCB through job satisfaction, that is $22.2 \%$.. The suggestion of this research are The next studies can use a wider and more extensive number of samples, and add more references and research reviews. So that research results are accurate. The next studies, research variables can be added such as job satisfaction, career development, compensation that can be investigated whether these variables can affect job satisfaction and OCB.

\section{ACKNOWLEDGEMENTS}

Thank you for the Institute for Research and Community Service (LPPM) of Universitas Negeri Jakarta who gave permission to conduct this research. Thank also for our friends who to give contribution in helping to collect data.

\section{AUTHOR CONTRIBUTION STATEMENTS}

Argo Ahmad (AA) was the main author in this paper. Dedi Purwana (DP) \& Adi Saptono (AS) was the second and the third author who provided support in being a comparative researcher. AA was as the main researcher. AA was researcher and developing methods. DP and AS helped researcher to evaluate the implementation of research

\section{REFERENCES}

Ahmadi, \& et al. (2011). Survey Relationship between OCB and Internal \& External Factors Impact on OCB. European Journal of Social Sciences, 16 No. 3. Google Scholar

Al-Swidi, A. K., Mohd, K. M. N., \& Asma, A. H. (2012). Is the Relatloship between Employees' Psychological Empowerment and Employees' Job Satisfaction Contingent on the Transformational Leadership? A Study on the Yemeni Islamic Banks. Asian Social Sciences, 8 No. 10(130-150). Google Scholar

Alif, A. (2015). Pengaruh Motivasi Kerja, Pengembangan Karir, dan Lingkungan Kerja terhadap Organizational Citizenship Behaviour (OCB) dengan Kepuasan Kerja sebagai Variabel Intervening pada Perusahaan Terminal LPG. MIX: Jurnal Ilmiah Manajemen, 5 No. 2.Google Scholar

Andreas, L. (2011). Dekonstruksi CSR dan Reformasi Paradigma Bisnis dan Akuntansi. Jakarta: Erlangga.Google Scholar

Aruan, Q. S., \& Fakhri, M. (2015). Pengaruh Lingkungan Kerja terhadap Kepuasan 
Kerja Karyawan Lapangan Departemen Grasberg Power Distribution PT Freeport Indonesia. Modus, 27 No. 2, 141-162. https://doi.org/10.24002/modus.v27i2.553

Asghar, S., \& Oino, I. (2018). Leadership Styles and Job Satisfaction. Market Forces, 13(1), 1-13. Google Scholar

Badeni. (2013). Kepemimpinan dan Perilaku Organisasi. Bandung: Alfabeta. Google Scholar

Budiyanto, \& Oetomo. (2011). The Effect of Job Motivation, Work Environment and Leadership on Organizational Citizenship Behavior, Job Satisfaction and Public Service Quality in Magetan East Java. Indonesian World Academy of Science, Engineering, and Technology, 75. Google Scholar

Danang, S. (2013). Teori, Kuesioner, dan Perilaku Organisasional. Jakarta: CAPS (Center for Academic Publishing Service). Google Scholar

Dewi, N. L., Yanti, P. A., \& Suwandana, I. G. M. (2016). Pengaruh Kepuasan Kerja terhadap Organizational Citizenship Behavior (OCB) dengan Komitmen Organisasional sebagai Variabel Mediasi. E-Jurnal Manajemen Unud, 5 No. 9, 56435670. Google Scholar

Fathoni, A. (2019). Organisasi dan Manajemen Sumber Daya Manusia. Bandung: Rineka Cipta. Google Scholar

Garay, H. D. V. (2006). Kinerja Extra-Role dan Kebijakan Kompensasi. Sinergi Kajian Bisnis Dan Manajemen, 8 No. 1, 33-42. Google Scholar

Boxall, P., \& Purcell, J. (2011). Strategy and human resource management. Macmillan International Higher Education.Google Scholar

Javed, H. A., Abbas, A., \& Rahim, J. M. (2014). Leadership Styles and Employees' Job Satisfaction: A Case from the Private Banking Sector of Pakistan. Journal of Asian Business Strategy. Google Scholar

Kartini, I. (2017). Pengaruh Gaya Kepemimpinan terhadap Organizational Citizenship Behavior (OCB) di Politeknik LP3I Jakarta Kampus Jakarta Utara. Jurnal Lentera Bisnis, 6 No. 1. http:/ / dx.doi.org/10.34127/jrlab.v6i1.168

Kirana, K. C., \& Ratnasari, R. T. (2017). Evaluasi Kinerja Sumber Daya Manusia (SDM). Google Scholar

Duha, T. (2018). Perilaku organisasi. Deepublish. Google Scholar

Maharani, V., Troena, E. A., \& Noermijati. (2013). Organizational Citizenship Behavior Role in Mediating the Effect of Transformational Leadership, Job Satisfaction, on Employee Performance: Studies in PT Bank Syariah Mandiri Malang East Java. International Journal of Business and Management, 8 No. 17. Google Scholar

Nasra, M. A., \& Heilbrunn, S. (2016). Transformational leadership and organizational citizenship behavior in the Arab educational system in Israel: The impact of trust and job satisfaction. Educational Management Administration \& Leadership, 44(3), 380-396. https:/ / doi.org/10.1177\%2F1741143214549975

Nawawi, H. H. (2018). Manajemen Sumber Daya Manusia untuk bisnis yang kompetitif. Google Scholar

Nielsen, T. M., Bachrach, D. G., Sundstrom, E., \& Halfhill, T. R. (2012). Utility of OCB : Organizational Citizenship Behavior and Group Performance in a RResouRce Allocation Framework. Journal of Management, 38 No. 2, 668-694. https:// doi.org/10.1177\%2F0149206309356326

Nurhayati, D., Maria, M. M., \& Heru, S. W. (2016). Pengaruh Kepuasan Kerja, Lingkungan Kerja, dan Loyalitas Kerja terhadap Organizational Citizenship Behavior (OCB) (Studi Kasus pada PT Perwirabhakti Sentrasejahtera di Kota Semarang). Journal of Management, 2 No. 2. Google Scholar 
Nurhidayah, A., \& Nurhattati, M. (2015). Organizational Culture and Work Environment: Its Effect on Teachers Organizational Citizenship Behavior (OCB). International Journal of Science and Research, 6(12).Google Scholar

Permana, L. F., Lely, S. W., \& Mufidah, A. (2016). Pengaruh Budaya Organisasi, Motivasi, Lingkungan Kerja terhadap Organizational Citizenship Behavior melalui Kepuasan Kerja pada PT Kereta Api Indonesia (Persero) Daerah Operasi 9 Jember. Google Scholar

Pitaloka, E., \& Sofia, I. P. (2014). The Affect of Work Environment, Job Satisfaction, Organization Commitment on OCB of Internal Auditors. International Journal of Business, Economics and Law, 5(2). Google Scholar

Priansa, D. J. (2014). Perencanaan dan Pengembangan SDM. Bandung: Alfabeta. Google Scholar

Dakir, H. (2019). Perencanaan dan pengembangan kurikulum. Rhineka Cipta. Google Scholar

Raziqa, A., \& Maulabakhsha, R. (2015). Impact of Working Environment on Job Satisfaction. Procedia Economics and Finance, 23, 717-725. https:// doi.org/10.1016/S2212-5671(15)00524-9

Robbins, S. P., \& Judge, T. A. (2011). Perilaku Organisasi. Jakarta: Salemba Empat. Google Scholar

Rohayati, A. (2014). Pengaruh Kepuasan Kerja Terhadap Organizational Citizenship Behavior: Studi Pada Yayasan Masyarakat Madani Indonesia. SMART-Study $\mathcal{E}$ Management Research, 11(1).Google Sholar

Salunke, G. (2015). Work Environment and Its Effect on Job Satisfaction in Cooperative Sugar Factories in Maharashtra, India. Bhinav International Monthly Refereed Journal of Research in Management \& Technology, 4(5). Google Scholar

Saxena, S., Tomar, K., \& Tomar, S. (2019). Impact of Job Satisfaction on Organizational Citizenship Behavior. In Proceedings of 10th International Conference on Digital Strategies for Organizational Success. https:/ / dx.doi.org/10.2139/ssrn.3323753

Sedarmayanti. (2001). Sumber Daya Manusia dan Produktivitas Kerja. Bandung: CV Mandar Maju. Google Scholar

Suhardi, \& Syaifullah. (2017). Pengaruh Motivasi, Kompetensi, Lingkungan Kerja, Kompensasi terhadap Organizational Citizenship Behavior dan Kinerja Karyawan Asuransi Jiwa di Provinsi Kepulauan Riau. Jurnal Benefita, 2(1), 55-71. Google Scholar

Supriadi, D., Soewarto, H., \& Rita, R. (2016). The Relationship of Transformational Leadership, Personality and Job Satisfaction to Organizational Citizenship Behavior (OCB). International Journal of Managerial Studies and Research (IJMSR), 4(11), 43-47. Google Scholar

Tabatabei, Takapoo, \& Leilaevoun. (2015). The Effective of Job Satisfaction on Organizational Citizenship Behavior. International Journal of Academic Research in Business and Social Sciences, 5(1). Google Scholar

Turnley, \& Bloodgood. (2002). Citizenship Behavior and the Creation of Social Capital in Organizations. The Academy of Management Review, 27(4), 505-522. Google Scholar

Wibowo. (2018). Manajemen Kinerja. Depok: Rajawali Pers. Google Scholar

Wibowo, M., Al-Musadieq, M., \& Nurtjahjono. (2014). "Pengaruh Lingkungan Kerja Terhadap Kepuasan Kerja Karyawan (Studi pada Karyawan PT.Telekomunikasi Indonesia Tbk. Kandatel Malang). Jurnal Administrasi Bisnis, 16. Google Scholar 